\title{
WELL-MANAGED FEARS OF THE CULTURE OF GLOBALIZATION: ORTHOREXIA
}

\author{
(C) Julia S. Khudina, Narine L. Wiegel, Julia O. Shishkanova \\ Rostov State Medical University, Rostov-on-Don, Russian Federation \\ science-almanac@mail.ru
}

The article deals with the influence of modern culture and society on the formation of the level of personality perception. Features of human interaction with environmental reality in extreme conditions (selfisolation period in conditions of COVID-19 pandemic) are considered separately. Features of social influence on formation of so-called social fears are shown. The problem of fear has its own history and remains relevant in modern society. Together with the development of society, fear takes on new forms, and unlike, for example, the fear of primitive man - darkness, loneliness and unclean power - the fears of modern man are directed by the cultural dominants of globalization into the field of science. Fear is not only inevitable, but also necessary, it is called upon to energize the forces of a person and stop him in moments of danger. Fear also has a number of negative qualities, directing human actions into a destructive channel. Only through rationalization is it possible to get away from a negative scenario to a positive one, thus managing your fear. The ability to adequately perceive reality, constructive marketing offers is the principle of common sense of a person. Analyzing a healthy lifestyle as a brand and direction of the culture of globalization, and in particular proper nutrition, the authors of the article call for a responsible approach to the new proposals of the consumption society in the context of the formation of human habits and lifestyle of the $21^{\text {st }}$ century.

Key words: beauty, proper nutrition, healthy lifestyle, controlled fears, globalization, orthorexia.

\section{[Ю.С. Худина, Н.Л. Вигель, Ю.О. Шишканова Управляемые страхи культуры глобализации: ор- торексия]}

Рассматриваются вопросы влияния современной культуры и социума на формирование уровня восприятия личности. Исследуются особенности взаимодействия человека с окружающей действительностью в экстремальных условиях (период самоизоляции в условиях пандемии COVID-19). Показаны особенности влияния социума на формирование так называемых социальных страхов. Проблема страха имеет свою историю и до сих пор остается актуальной в современном обществе. Вместе с развитием общества страх приобретает новые формы, и в отличие, к примеру, от страха первобытного человека - темноты, одиночества и «нечистой силы», - страхи современного человека направляются культурными доминантами глобализации в область научности. Страх является не только неизбежностью, но и необходимостью, он призван активизировать силы человека и останавливать его в моменты опасности. Страх обладает и рядом отрицательных качеств, направляя действия человека в деструктивное русло. И только благодаря рационализации есть возможность уйти от отрицательного сценария к положительному, таким образом управляя своим страхом. Способность к адекватному восприятию действительности есть принцип здравого смысла человека. Анализируя здоровый образ жизни как бренд и направление культуры глобализации, а в частности, правильное (здоровое) питание, авторы статьи призывают к ответственному подходу к новым предложениям общества потребления в контексте формирования привычек и образа жизни человека XXI века.

Ключевые слова: красота, правильное питание, здоровый образ жизни, управляемые страхи, глобализация, орторексия.

Julia S. Khudina - Assistant Professor, Department of Psychiatry, Rostov State Medical University, Rostovon-Don, Russian Federation.

Narine L. Wiegel - Ph.D. (Advanced Doctorate) in Philosophy, Professor, Rostov State Medical University, Rostov-on-Don, Russian Federation.

Julia O. Shishkanova - Student, Rostov State Medical University, Rostov-on-Don, Russian Federation.

Худина Юлия Сергеевна - ассистент, кафедра психиатрии, Ростовский государственный медицинский университет, г. Ростов-на-Дону, Российская Федерация. 
Вигель Нарине Липаритовна - доктор философрских наук, профрессор, Ростовский государственный медицинский университет, г. Ростов-на-Дону, Российская Федерация.

Шишканова Юлия Олеговна - студент, Ростовский государственный медицинский университет, е. Ростов-на-Дону, Российская Федерация.

The beginning of the $21^{\text {st }}$ century was marked by another global crisis, which affected almost all spheres of modern life. Society is "divided" into globalists and traditionalists, who offer their own principles for overcoming the global crisis [14]. The culture of corporeality did not stand aside, which, in contrast to the ideals of previous worldview positions, offers standards that are widely demanded in the culture of globalization [3]. The fear of being rejected and misunderstood in society, the fear of not conforming to the canons of the beauty of modern society, whipped up in the media, went beyond the biological function and began to play an important role in the formation of culture and morality. It is used in religion and the media, in economics and politics, in psychology and marketing, because fear is at the core of our worldview. In accordance with the imposed controlled fears, a whole beauty industry has emerged that allows a person to change himself according to a standardized beauty cliché [9]. The active change in appearance began with the notorious "standards" of beauty, which at first were available only to the "elite". The fact of studying the issues of "beauty", as well as its influence on society and on life in it, was also important [2]. The massive availability of body transformation has become the reality of today. And even age restrictions and financial spending are often not an obstacle on the way to the "standard Barbie ideal." The cult of Barbie meaning the cult of youth, bodily beauty, the clarity of consciousness by the previous experience of a thousand-year civilization feels much better in the fair-haired and calmly sincere Barbie - the main article of each annual collection of Mattel Incorporated.

In an effort to achieve this ideal, the human body is often stressed. But often, stress is a trigger mechanism for triggering an emotion like fear. Social fears are believed to merit particular attention. They are the important regulatory factor of personal behavior [11]. Fear, in turn, underlies anxiety, which later begins to "absorb" a person. Obsessions join at different stages of this interaction. Everything that happens begins to resemble a snowball with which a person is struggling. Often this struggle resembles one of the oldest symbols - Ouroboros - also known as the snake biting its own tail. Even the temporary unattainability of desire generates stress, which "forces" the desire to change and transform in the conditions of unstable fashion in society to infinity [15].

The history of beauty and changes in appearance did not stand still: arsenic in lip color paste, belladonna drops for shine eyes, vinegar for pale skin and more. What tricks did the beauties of the past go to? With the development of a new level of medicine, more radical methods in the form of surgical intervention were used. Surgical techniques have been replaced by more gentle ones. Aesthetic surgeons and beauticians have been replaced by nutritionists and fitness coaches. From their lips more and more often the flock sounds the concepts of "healthy lifestyle", "proper nutrition" and incomprehensible foreign words - "workout", "stretching", "pilates" and so on. All of this has become practically part of the new world political ideology. From each "iron" calls for "correctness" sound, "organic shops" and stores of the right products open. But this newfangled aspect has acquired negative features in the form of obsession with this very notorious "correctness". It was named "orthorexia nervosa".

The analysis of theoretical and methodological research shows that the modern understanding of "healthy lifestyle" is characterized, first of all, as a certain structure of the individual's life, focused on the dominants of the culture of globalization. In a healthy lifestyle, the relationship between social and personal, the dialectical unity of the socially directed and individually unique in the behavior of an individual person is manifested. In oth- 
er words, the concept of a "healthy lifestyle" in this article is considered in the context of the sociology of culture, where the reaction of a person to social fears is investigated, which not only construct moral attitudes and cultural stereotypes of behavior, but also, through anxiety, alert encroach on human mental health.

For the first time the term "orthorexia nervosa" was mentioned according to some sources in 1996, and according to others - a year later, by a practicing physician from San Francisco (USA) Stephen Bratman. He described patients who were not just striving for "healthy eating", but experienced something akin to an obsession. For more than two decades, the study of orthorexia has allowed to form the final concept of the disease. According to R. McGregor, dysmorphomania and dysmorphobia are not always characteristic of this manifestation. Much more often we are talking about proper nutrition, as a "tool to achieve harmony with oneself" [4].

Bratman described an obsessive adherence to "eating rules" (this applies to strict restrictions, including self-invented, feelings of guilt when deviating from restrictions, the inability to eat outside the home, etc.). Other researchers talk about anxiety and perfectionism, inherent in orthorexia and obsessive-compulsive disorder [16].

According to the latest data from some scientists, excessive quality control of food products can result in so-called orthorexia nervosa [18]. Consequently, the results of the absence of statistical differences in gender samples were obtained. [12] Difficulties in identifying and regulating emotions were also found [19]. It must be remembered that emotional disorders, regardless of the etiology of occurrence, are quite important in terms of detection and relief [4], and in the modern world they can be indirectly dependent on the environment and the risks it carries.

However, some authors propose to critically evaluate orthorexia and find contradictions for the formulation of this diagnosis as an independent nosological unit [17]. In this connection, a dispute arises about what is nervous orthorexia - a mental disorder or a new social trend?! [8]. In the course of the study, we decided to find out if there are predictors of orthorexia in medical university students, and also to find out if they have differences in eating behavior during the period of everyday life (pre-self-isolation period) and during selfisolation.

Scientific hypothesis: social factors (including those associated with large-scale disasters and epidemics) have a significant impact on the way of life. The aim of our research was an attempt to study the influence of the level of isolation and social fear during the epidemic on the way of life.

Methods. The study was carried out in two stages at the Rostov State Medical University. The first phase of the study was conducted in February 2020. The second phase of the study was due to the introduction of a self-isolation regime and was carried out in May 2020. 80 students of both sexes of the pediatric faculty and the faculty of the military training center (UVC) were interviewed (including with the use of modern computer technologies). The same people took part in both parts of the study (for the purity of the experiment). The author's questionnaire was used, the Bratman test (a 10-item simple dichotomy scale test for assessing orthorexia; named after its inventor) and the ORTO-15 test (a test of 15 closed-ended questions in the simple choice option, which assesses beliefs on the perceived effects of eating healthy food) [13] for a voluntary survey in the intermediate (including distance) learning cycle. Statistical processing was carried out by primary and secondary analysis, using the MS Excel 2007 program. Inclusion criteria: training at the pediatric faculty and the faculty of the UVC Rostov State Medical University.

In the first phase of the study, we tried to track the trend towards healthy / healthy eating habits. A positive answer to the question of following a correct / healthy diet was given by 30 respondents out of 80 . In percentage terms, the positive answer was $37.5 \%$. 
During the period of self-isolation, the number of students leading healthy / proper nutrition increased by $20.0 \%$ compared to the initial survey and amounted to 36 people. It is noteworthy that the growth of this indicator was due to the gender sample of girls, which increased by $39.1 \%$ by the second phase of the study. The percentage of young men who adhere to this lifestyle during the period of self-isolation decreased by $42.9 \%$. The quantitative indicator practically approached half of the sample, which allows us to speak about the influence of the self-isolation regime as a social factor on the response rate.

One of the questions turned out to be the following: Do you strive to explain to others the need for "healthy / proper nutrition"? A similar desire to explain to others (relatives, friends, unfamiliar people, including in social networks) by the second phase increased by almost a third (27.3\%) from 22 to 28 people. The growth, as in the previous question, was due to an increase in the gender sample of girls and a decrease in the gender sample of boys. The number of girls increased by $60.0 \%$ from the original survey, while the number of boys decreased by $42.9 \%$. An increase in this indicator during the period of self-isolation and quarantine measures allows us to indirectly talk about social fears and the desire to avoid an impending problem through recovery.

One of the important aspects is the affective state, which can deform moral feelings, as well as negatively affect the state of society as a whole. If in the first phase 34 respondents spoke about mood swings before and after eating, then in the second phase there was a decrease by almost a third (29.4\%) and turned out to be equal to 24 . The increase was due to the increase in respondents with positive answers in both gender samples. In the gender sample of girls by the second phase of the study, there was an increase by $25.0 \%$, and in the sample of boys - by $125.0 \%$ ! Which only emphasizes the importance of affective pathology (in the form of mood disorders) in the modern world.

Obsession with the presence of certain products in the refrigerator was noted by more than half of the respondents (62.5\%). In gender samples, the percentage of positive answers was $79.2 \%$ for girls and $37.5 \%$ for boys. In comparison with the first stage, there was an increase, as in the previous questions, due to an increase in the number of girls.

In the first phase of the research, the following results were obtained: according to the Bratman test, the number of respondents with a mark exceeding the norm and indicating a predictor of orthorexia was 12 (9 girls, 3 boys); and ORTO-15 - 30 people (17 girls, 13 boys). At the same time, only 4 students (3 girls, 1 boy) showed coincidences on both questionnaires.

In the second phase of the research, the following results were obtained: according to the Bratman test, the number of respondents with a mark exceeding the norm and being a possible predictor of orthorexia was 20 (17 girls, 3 boys); and ORTO-15 - 46 people (29 girls, 17 boys). At the same time, only 8 students ( 7 girls, 1 boy) showed coincidences on both questionnaires.

The results obtained allow us to speak about the significant influence of society on the way of life, including during the period of self-isolation. Like any influence, it has positive and negative aspects. As a positive aspect during the period of self-isolation, we can talk about an increase in the number of respondents trying to lead a healthy lifestyle and observe a healthy diet.

The growth of positive answers to some questions in the second stage of the study due to the gender sample of girls, from our point of view, can be explained by the susceptibility to social fears for several reasons. Firstly, due to excessive impressionability, which may be a consequence of the personal characteristics of the respondents. Second, social fears could have replaced biological ones. It is not possible to assess the full-fledged evidential mechanism of the emergence of social fears in this article, since requires further close study with immersion in the genesis of phobic disorders. 
Negative features were manifested in a direct relationship between adherence to a healthy diet and a numerical increase in positive responses (the number of respondents exceeding the values on the scales was 100.0\%), which made it possible to speak about the parameters of the possible occurrence of orthorexia during the second phase of the study.

Thus, we can say with confidence that social fear refers to those types of fear that affect social mood, and, as a result, not only have a significant impact on the way of life, but also contribute to its (way of life) sustainable formation. In connection with the development of the culture of globalization and marketing decisions that determine the formation of modern culture of the XXI century, new types of social fears arise, since they are somehow connected with social situations, with social reality, the aggravating factor of which is the gradual atomization of society, isolation (both voluntary and and forced). These scenarios are well described in The Plague by Albert Camus and Medical Historical Studies by Michel Foucault. A situation when weak ties disappear, and personal preferences are increasingly subject to a manipulated and controlled culture of globalization, which promotes modern dominants and cultural trends through the media, losing the layer of sociality that was accumulated in the mode of routine functioning.

\section{Лumepamypa}

1. Блейхер В.М., Крук И.В. Толковый словарь психиатрических терминов. 1995. Воронеж: МОДЭК, 1995. 640 с.

2. Вигель Н.Л. Вкус как социокультурный феномен // Региональная история: методология, источники, историография Сборник научных трудов III Международных Усмановских чтений. 2016. С. 245-248.

3. Вигель Н.Л. Проблема диалога культур в современности // Экономические и гуманитарные исследования регионов. 2015. № 4. С. 100-104.

4. Дмитриев М.Н., Худина Ю.С. Афрфективные расстройства как угроза национальной безопасности // Современные проблемы безопасности жизнедеятельности: настоящее и будущее. Материалы III Международной научнопрактической конференции. г. Казань. 2014. С. 346-355.

5. Курпатов А.В., Аверьянов Г.Г. Психосоматика. Психотерапевтический подход. 2019, М.: Капитал. 480 с.

6. Макгрегор Р. Когда здоровое питание вредит. Орторексия. Альпина Паблишер. M., 2018. $180 \mathrm{C.}$

7. Менделевич В.Д. Клиническая и медицинская психология: Учебное пособие. М.: Медпресс-информ, 2008. 432 с.

8. Руженков В.А., Захарова Л.И., Хамская И.С., Руженкова В.В., Колосова М.А., Минакова Ю.С. Русскоязычная адаптация теста «ORTO-15» для скринингдиагностики нервной орторексии // Вестник психиатрии, неврологии и нейрохирургии. 2019. № 8. с. 27-36.

9. Тутова 3.О., Койчуев А.Г., Пшунов Т.С., Худина Ю.С. Изменения внешности: две стороны одной медали // Polish journal of science. 2019. № 22 (2). с. 57-59.

10. Чайка Ю.Ю. Первичный страх, тревога и бредовое настроение // Український вісник психоневрологіi. 2002. Т. 10, Вип. 2. с. 149-150.

11. Ярушкин Н.Н., Сатонина Н.Н. Социальный страх как регулятор ответственного поведения личности // Вестник Самарской гуманитарной академии. Серия: Психология. 2007. № 1. с. 78-84.

12. Brytek-Matera A., Donini L.M., Krupa M., Poggiogalle E., Hay P. Orthorexia nervosa and self-attitudinal aspects of body image in female and male university students 
[published correction appears in J Eat Disord. 2016; 4:16]. J Eat Disord. 2015; 3:2. Published 2015 Feb 24. doi:10.1186/s40337-015-0038-2

13. Donini LM, Marsili D, Graziani MP, et al. Orthorexia nervosa: validation of a diagnosis questionnaire. Eat Weight Disord. 2005;10(2):e28-e32

14. Enquist M., Ghirlanda S., Eriksson K. Modelling the Evolution and Diversity of Cumulative Culture. Philosophical Transactions of the Royal Society of London. Series B, Biological Sciences. Published 2011 Feb 12; 366(1563):412-23. doi: 10.1098/rstb.2010.0132.

15. Grupe D.W., Nitschke J.B. Uncertainty and anticipation in anxiety: an integrated neurobiological and psychological perspective. Nature Reviews. Neuroscience. Published 2013 Jul; 14(7):488-501. doi:10.1038/nrn3524

16. Mathieu J. What is orthorexia? J Am Diet Assoc. Published 2005; 105(10):15101512. doi:10.1016/j.jada.2005.08.021

17. Strahler J., Stark R. Perspective: Classifying Orthorexia Nervosa as a New Mental Illness-Much Discussion, Little Evidence [2020 Feb 14]. Adv Nutr. 2020;nmaa012. doi:10.1093/advances/nmaa012

18. Voglino G, Parente E, Bert F, et al. Orthorexia Nervosa, a challenging evaluation: analysis of a sample of customers from organic food stores [2020 May 25]. Psychol Health Med. Published 2020; 1-9. doi:10.1080/13548506.2020.1771386.

19. Vuillier L, Robertson S, Greville-Harris M. Orthorexic tendencies are linked with difficulties with emotion identification and regulation. J Eat Disord. 2020; 8:15. Published 2020 Apr 23. doi:10.1186/s40337-020-00291-7

\section{References}

1. Bleykher V.M., Kruk I.V. Tolkovyy slovar psikhiatricheskikh terminov [Defenition Dictionary of Psychiatric Terms]. 1995. Voronezh: NPO «MODEK», 1995. 640 p. (In Russian).

2. Vigel N.L. Vkus kak sotsiokulturnyy fenomen [Taste as a sociocultural phenomenon]. Regionalnaya istoriya: metodologiya, istochniki, istoriografiya. Sbornik nauchnykh trudov III Mezhdunarodnykh Usmanovskikh chteniy. 2016. pp. 245-248 (In Russian).

3. Vigel N.L. Problema dialoga kultur v sovremennosti [The problem of the dialogue of cultures in modern times]. Ekonomicheskiye i gumanitarnyye issledovaniya regionov. 2015. No. 4. pp. 100-104 (In Russian).

4. Dmitriyev M.N., Khudina Yu.S. Affektivnyye rasstroystva kak ugroza natsionalnoy bezopasnosti [Affective disorders as a threat to national security]. Sovremennyye problemy bezopasnosti zhiznedeyatelnosti: nastoyashcheye i budushcheye. Materialy III Mezhdunarodnoy nauchno-prakticheskoy konferentsii. Kazan. 2014. pp. 346-355 (In Russian).

5. Kurpatov A.V., Averyanov G.G. Psikhosomatika. Psikhoterapevticheskiy podkhod [Psychosomatics. Psychotherapeutic approach]. 2019, Moscow: Kapital. 480 p. (In Russian).

6. McGregor R. Kogda zdorovoye pitaniye vredit. Ortoreksiya [When healthy eating hurts. Orthorexia.]. Alpina Publisher. Moscow, 2018. 180 p. (In Russian).

7. Mendelevich V.D. Klinicheskaya i meditsinskaya psikhologiya: Uchebnoye posobiye [Clinical and Medical Psychology: Textbook]. Moscow: Medpress-inform, 2008. 432 p. (In Russian). 
8. Ruzhenkov V.A., Zakharova L.I., Khamskaya I.S., Ruzhenkova V.V., Kolosova M.A., Minakova Yu.S. Russkoyazychnaya adaptatsiya testa «ORTO-15» dlya skriningdiagnostiki nervnoy ortoreksii [Russian-language adaptation of the ORTO-15 test for screening diagnostics of nervous orthorexia]. Vestnik psikhiatrii, nevrologii i neyrokhirurgii. 2019. No. 8. pp. 27-36 (In Russian).

9. Tutova Z.O., Koychuyev A.G., Pshunov T.S., Khudina Yu.S. Izmeneniya vneshnosti: dve storony odnoy medali [Changes in appearance: two sides of the same coin]. Rolish journal of science. 2019. No. 22 (2). pp. 57-59 (In Russian).

10. Chayka Yu.Yu. Pervichnyy strakh, trevoga i bredovoye nastroyeniye [Primary fear, anxiety and delusional mood]. Ukraïnskiy visnik psikhonevrologii. 2002. V. 10 (2). pp. 149-150 (In Russian).

11. Yarushkin N.N., Satonina N.N. Sotsialnyy strakh kak regulyator otvetstvennogo povedeniya lichnosti [Social fear as a regulator of responsible personality behavior]. Vestnik Samarskoy gumanitarnoy akademii. Seriya: Psikhologiya. 2007. No. 1. pp. 78-84.

12.Brytek-Matera A., Donini L.M., Krupa M., Poggiogalle E., Hay P. Orthorexia nervosa and self-attitudinal aspects of body image in female and male university students [published correction appears in J Eat Disord. 2016; 4:16]. J Eat Disord. 2015; 3:2. Published 2015 Feb 24. doi:10.1186/s40337-015-0038-2

13.Donini L.M., Marsili D, Graziani M.P. et al. Orthorexia nervosa: validation of a diagnosis questionnaire. Eat Weight Disord. 2005;10(2):e28-e32

14. Enquist M., Ghirlanda S., Eriksson K. Modelling the Evolution and Diversity of Cumulative Culture. Philosophical Transactions of the Royal Society of London. Series B, Biological Sciences. Published 2011 Feb 12; 366(1563):412-23. doi: 10.1098/rstb.2010.0132.

15. Grupe D.W., Nitschke J.B. Uncertainty and anticipation in anxiety: an integrated neurobiological and psychological perspective. Nature Reviews. Neuroscience. Published 2013 Jul; 14(7):488-501. doi:10.1038/nrn3524

16. Mathieu J. What is orthorexia? J Am Diet Assoc. Published 2005; 105(10):15101512. doi:10.1016/j.jada.2005.08.021

17.Strahler J., Stark R. Perspective: Classifying Orthorexia Nervosa as a New Mental Illness-Much Discussion, Little Evidence [published online ahead of print, 2020 Feb 14]. Adv Nutr. 2020;nmaa012. doi:10.1093/advances/nmaa012

18. Voglino G, Parente E, Bert F. et al. Orthorexia Nervosa, a challenging evaluation: analysis of a sample of customers from organic food stores [published online ahead of print, 2020 May 25]. Psychol Health Med. Published 2020; 1-9. doi:10.1080/13548506.2020.1771386.

19. Vuillier L, Robertson S, Greville-Harris M. Orthorexic tendencies are linked with difficulties with emotion identification and regulation. J Eat Disord. 2020; 8:15. Published 2020 Apr 23. doi:10.1186/s40337-020-00291-7 